\title{
Halogens and the chemistry of the free troposphere
}

\author{
D. J. Lary ${ }^{1,2}$ \\ ${ }^{1}$ Global Modelling and Assimilation Office, NASA Goddard Space Flight Center, Greenbelt, MD, USA \\ ${ }^{2}$ GEST at the University of Maryland Baltimore County, Baltimore, MD, USA
}

Received: 20 August 2004 - Published in Atmos. Chem. Phys. Discuss.: 16 September 2004

Revised: 12 November 2004 - Accepted: 26 January 2005 - Published: 27 January 2005

\begin{abstract}
The role of halogens in both the marine boundary layer and the stratosphere has long been recognized, while their role in the free troposphere is often not considered in global chemical models. However, a careful examination of free-tropospheric chemistry constrained by observations using a full chemical data assimilation system shows that halogens do play a significant role in the free troposphere. In particular, the chlorine initiation of methane oxidation in the free troposphere can contribute more than $10 \%$, and in some regions up to $50 \%$, of the total rate of initiation. The initiation of methane oxidation by chlorine is particularly important below the polar vortex and in northern mid-latitudes. Likewise, the hydrolysis of $\mathrm{BrONO}_{2}$ alone can contribute more than $35 \%$ of the $\mathrm{HNO}_{3}$ production rate in the freetroposphere.
\end{abstract}

\section{Introduction}

Halogens play a variety of roles in atmospheric chemistry. Most notable is their involvement in catalytic ozone loss and the formation of the stratospheric ozone hole (Johnston and Podolske, 1978; Cicerone et al., 1983; Farman et al., 1985). Like $\mathrm{OH}$, they are also involved in the initiation and catalysis of hydrocarbon oxidation and consequently also play a role in the partitioning of $\mathrm{OH}$ and $\mathrm{HO}_{2}$. Similarly they are involved with the partitioning of $\mathrm{NO}$ and $\mathrm{NO}_{2}$. Some of the same reactions involved in ozone hole chemistry also lead to the production of nitric acid, namely the hydrolysis of $\mathrm{BrONO}_{2}$ and $\mathrm{ClONO}_{2}$ on sulphate aerosols. These roles are well known and accepted when stratospheric chemistry is being discussed (DeMore et al., 2000). The role of halogens is also important in the marine boundary layer (Vogt et al., 1996; Sander and Crutzen, 1996; Richter et al., 1998;

Correspondence to: D. J. Lary

(David.Lary@umbc.edu)
Dickerson et al., 1999; Sander et al., 2003; von Glasow and Crutzen, 2004; von Glasow et al., 2004). Hendricks et al. (1999) presented box model calculations on the impact of heterogeneous reactions of nitrogen, chlorine, and bromine compounds on the chemistry of the mid-latitude tropopause region. von Glasow et al. (2004) recently used observations and a GCM to look at the role of $\mathrm{BrO}$ in the troposphere. However, when the chemistry of the free troposphere is considered the role of chlorine is not normally considered important.

A chemical data assimilation analysis using a full Kalman filter (Fisher and Lary, 1995; Lary et al., 2003; Lary, 2003; Lary et al., 1995b; Lary, 1996) (http://gest.umbc.edu/ AutoChem/) starting in October 1991 and continuing till December 1998 reveals that halogens are also playing a significant role in the chemistry of the free troposphere. Comprehensive results from the analysis are also available online at http://gest.umbc.edu/CDACentral/. Section 2 describes the analysis system. Section 3 describes the observations used and how they are handled. Section 4 describes our uncertainty analysis. Section 5 describes the chemical Kalman filter. Section 6 describes the results relevant to methane oxidation. Section 7 describes the role of halogen compounds in the production of nitric acid. Section 8 describes the role of halogen compounds in the partitioning of $\mathrm{OH}$ and $\mathrm{HO}_{2}$. Section 8 describes the role of halogen compounds in the partitioning of $\mathrm{NO}$ and $\mathrm{NO}_{2}$. Section 10 resents the conclusions.

\section{Analysis System}

This section describes the basic elements of the analysis system infrastructure. A hyperlinked schematic of the chemical assimilation system and automatic code generator and documentor is available online at http://gest.umbc.edu/ AutoChem/Schematic.html.

(C) 2005 Author(s). This work is licensed under a Creative Commons License. 


\subsection{Automatic Code Generation}

This study used AutoChem, an automatic code generator and documenter for atmospheric chemistry. Given a set of reaction databases and a user supplied list of required species it will automatically select the reactions involving those constituents. It then constructs the ordinary differential equation (ODE) time derivatives, symbolically differentiates the time derivatives to give the Jacobian, and symbolically differentiates the Jacobian to give the Hessian. It also documents the whole process in a set of LaTeX and PDF files.

The subset of reactions involving the user specified constituents is extracted by the first AutoChem preprocessor program called Pick. This subset of reactions is then used by the second AutoChem preprocessor program RoC (rate of change) to generate the time derivatives, Jacobian, and Hessian. Once the two preprocessor programs have been run all the Fortran90 code has been generated that is necessary for modelling and assimilating the kinetic processes. An online manual of AutoChem is available at http://gest.umbc. edu/AutoChem/.

\subsection{Radiative Transfer Calculation of Photolysis Rates}

A key part of the chemical model is the calculation of photolysis rates. In this study they are calculated using full spherical geometry and multiple scattering (Anderson, 1983; Lary and Pyle, 1991a,b; Meier et al., 1982; Nicolet et al., 1982) corrected after Becker et al. (2000). The photolysis rate used for each time step is obtained by ten point GaussianLegendre integration of the photolysis rate over the time step (Press et al., 1992). The photolysis rates are looked up in a photolysis rate tabulation which is updated every day for each latitude band to ensure that the current ozone and temperature profiles are used to calculate the photolysis rates. A total of 203 wavelength intervals are used from 116.7 to $850 \mathrm{~nm}$ (WMO, 1986). Daily solar irradiances are used for each of the 203 wavelength intervals. The surface albedo used for each latitude band is the median albedo observed by TOMS for that month.

\subsection{Flow-Tracking Coordinates}

Because a major component of the variability of trace gases is due to the atmospheric motions it makes sense to use a coordinate system that 'moves' with the large scale flow pattern to perform our analyses. In this study Lagrangian flowtracking coordinates are used.

Under adiabatic conditions air parcels move along isentropic surfaces (surfaces of constant potential temperature, $\theta$ ). So when considering tracer fields $\theta$ is a suitable vertical coordinate, since it acknowledges the likely vertical motion of air parcels. McIntyre and Palmer (1983, 1984); Hoskins et al. (1985), and Hoskins (1991) have shown the value of isentropic maps of Ertel's potential vorticity (PV) in visu- alising large scale dynamical processes. PV is an approximate material tracer for motion along isentropic surfaces only (Haynes and McIntyre, 1990). PV plays a central role in large scale dynamics where it behaves as an approximate material tracer (Hoskins et al., 1985).

As a result, PV can be used as the horizontal spatial coordinate instead of latitude and longitude (Norton, 1994; Lary et al., 1995a). PV is sufficiently monotonic in latitude on an isentropic surface to act as a useful replacement coordinate for both latitude and longitude, reducing the tracer field from three dimensions to two. These ideas have already led to interesting studies correlating PV and chemical tracers such as $\mathrm{N}_{2} \mathrm{O}$ and $\mathrm{O}_{3}$ (Schoeberl et al., 1989; Schoeberl and Lait, 1992; Proffitt et al., 1989, 1993; Lait et al., 1990; Douglass et al., 1990; Proffitt et al., 1989, 1993; Atkinson, 1993). A key result of these studies is that PV and ozone mixing ratios are correlated on isentropic surfaces in the lower stratosphere (Danielsen, 1968).

Since the absolute values of PV depend strongly upon height and the meteorological condition, it is useful to normalise PV and use PV equivalent latitude $\left(\phi_{e}\right)$ as the horizontal coordinate instead of PV itself. $\phi_{e}$ is calculated by considering the area enclosed within a given PV contour on a given $\theta$ surface. The $\phi_{\mathrm{e}}$ assigned to every point on this PV contour is the latitude of a latitude circle which encloses the same area as that PV contour. Therefore, for every level in the atmosphere $\phi_{\mathrm{e}}$ has the same range of values, $-90^{\circ}$ to $90^{\circ}$. This provides a vortex-tracking, and indeed a flow-tracking, stratospheric coordinate system.

\subsection{Analyses Grid}

The analyses grid used in this study is cast in equivalent PV latitude, potential temperature coordinates. With 32 latitudes between $80^{\circ} \mathrm{S}$ and $80^{\circ} \mathrm{N}$, and 24 logarithmically spaced isentropic surfaces between the earth's surface and $2400 \mathrm{~K}$. The grid resolution was carefully chosen to ensure that there is usually a statistically significant number of observations per analysis grid cell. This allows meaningful representativeness uncertainty statistics to be calculated based on the observations alone. As the potential temperature at the surface changes with time we use a fixed number of isentropic levels between the surface potential temperature for a given day and equivalent latitude band and $500 \mathrm{~K}$, above $500 \mathrm{~K}$ the levels remain fixed with time. The isentropic levels correspond approximately to the UARS surfaces spaced at 6 per decade in pressure (c.f. the UARS reference atmosphere levels http://code916.gsfc.nasa.gov/Public/Analysis/ UARS/urap/home.html).

\section{Observations}

The key difference between conventional modelling and data assimilation is the use of observations and information on 

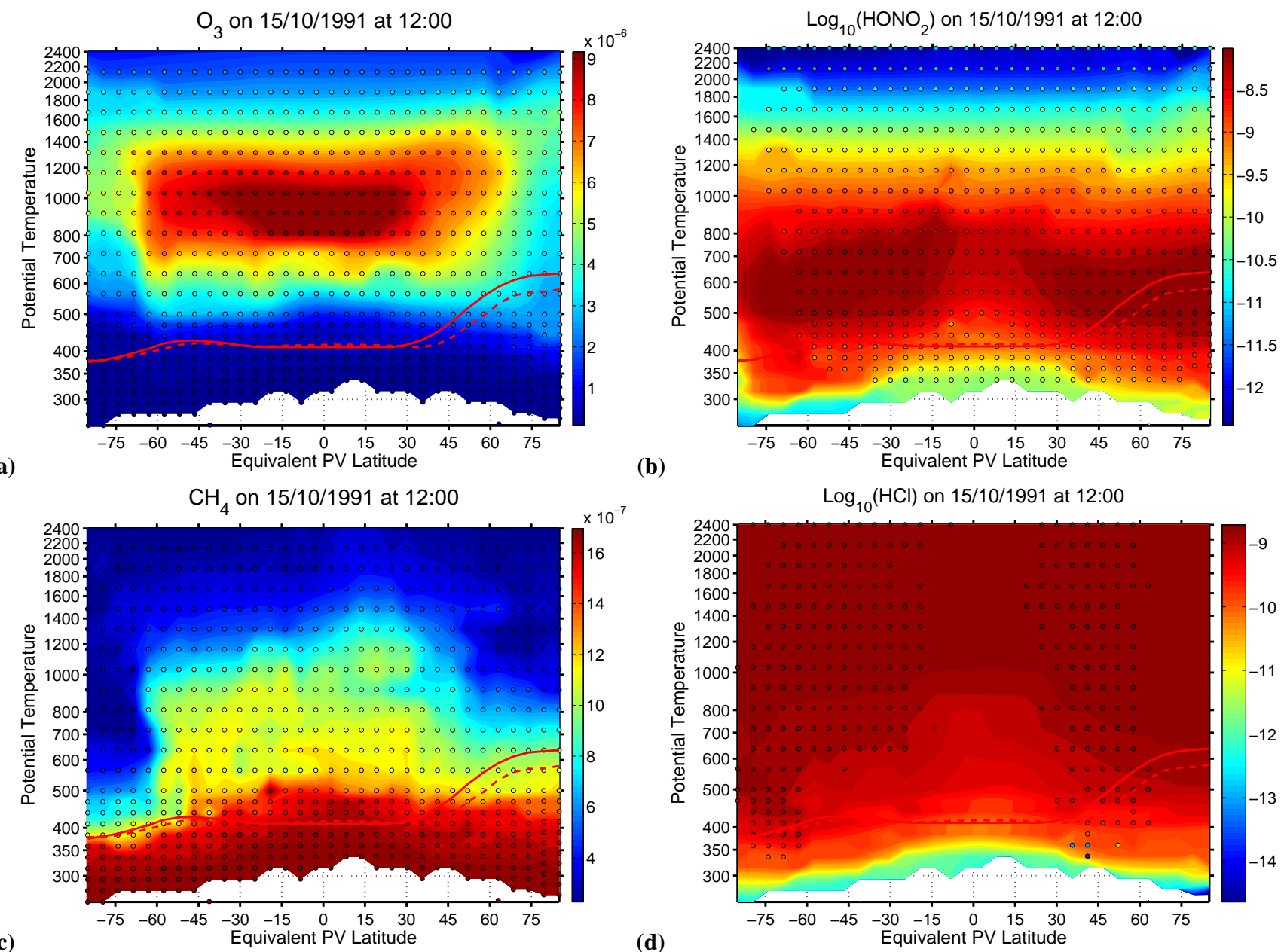

Fig. 1. Panels (a) to (d) show the global ozone, nitric acid, methane and hydrochloric acid analyses from the surface up to the lower mesosphere produced by chemical data assimilation for October 15, 1991 at local solar noon. The analyses are presented as equivalent PV latitude - potential temperature cross sections. The background colors show the volume mixing ratio (in the case of $\mathrm{HNO}_{3}$ and $\mathrm{HCl} \log _{10}$ of the v.m.r.) and the overlaid color filled circles show the observations used. The thick red line overlaid on the plots is the thermal tropopause diagnosed from the UKMO analyses minimum temperature, the dashed red line is the tropopause diagnosed using the WMO lapse rate definition. The white space at the bottom of the plots is because the analysis is terrain following and the surface potential temperature changes with time and location. It can be seen that although the bulk of the observations are in the stratosphere many observations are also available below the tropopause.

observational and other uncertainties (described in the next section). In this study for each analysis grid cell we consider a probability distribution function (PDF) of all the available observations. The 'observation' used by the assimilation system for a given grid cell is the median value of the PDF. The criteria used to determine at what location we use an observation are equivalent PV latitude $\left(\phi_{e}\right)$, and potential temperature $(\theta)$. An observation is used in $\phi_{e}-\theta$ grid box where it lies. That means that no interaction between the boxes (meridional transport, mixing, diabatic ascent/descent) is considered.

Two criteria were used in choosing which observations to assimilate. First, we chose constituents for which we had observations over the entire period of 1991 to 1998. Second, where more than one instrument was observing a con- stituent we chose to use instruments that did not have significant relative biases. This was determined by looking at observation PDFs. This analysis is also available online at: http://gest.umbc.edu/PDFCentral/.

There appears to be good consistency between the sporadic observations of missions such as ATMOS and CRISTA with the long-term HALOE and MLS data-sets used. This was not the case for some possible combination of observations. For example, CLAES ozone and MLS ozone had some large differences. After conducting the PDF analyses it seems that the major problems are with CLAES. Another example is MLS, HALOE and SAGE water, SAGE water was not used after the results of the PDF analyses showed it has bias issues. 
The resulting assimilated analyses are presented online, where observations were used these are overlaid on the assimilated analyses (http://gest.umbc.edu/CDACentral/) as color-filled circles using the same color scale as the colorfilled contours used to depict the analyses. This allows appropriate comparison with observations to validate the assimilation. In addition, when observations of a constituent were used the web site also provides an assimilation statistics page (at the top of each page just below the java-script calendar bar). This page presents the observations, the various observation uncertainties, and the assimilation skill scores.

This study used sulphate aerosol observations from SAGE II (Ackerman et al., 1989; Oberbeck et al., 1989; Russell and McCormick, 1989; Thomason, 1991, 1992; Bauman et al., 2003) and HALOE (Hervig et al., 1993, 1996; Hervig and Deshler, 1998; Massie et al., 2003), ozone observations from UARS (Reber et al., 1993) MLS v6 (Froidevaux et al., 1996; Waters, 1998), HALOE v19 (Russell et al., 1993), POAM, ozone sondes and LIDAR, nitric acid observations from UARS MLS v6 (Santee et al., 1997, 1999), CLAES, ATMOS, CRISTA (Offermann and Conway, 1999) and ILAS (Wood et al., 2002), hydrochloric acid observations from UARS HALOE and ATMOS, water observations from UARS HALOE v19, ATMOS and MOZAIC (Marenco et al., 1998), methane observations from UARS HALOE v19, ATMOS and CRISTA were used. Although the bulk of these observations were in the stratosphere a significant number of satellite observations were available for the free troposphere down to $5 \mathrm{~km}$, and from sondes and aircraft data is also available below $5 \mathrm{~km}$ (e.g. Fig. 1).

\section{Uncertainties}

This section describes the treatment of uncertainties of both the observations and the model.

\subsection{Observational Uncertainties}

A key feature of this study is the quantification of a suite of uncertainties associated with the observations all on the analyses grid. The uncertainties provided are: The observational uncertainty as supplied by the instrument teams. The representativeness uncertainty, i.e. the concentration variability over the analyses grid cell. The Kriging uncertainty, i.e. the uncertainty associated with filling in the data gaps. The total uncertainty due to all of the above. The representativeness uncertainty is calculated by taking the average deviation of the tracer concentrations from the median from the given grid cell.

\subsection{Observation Sanity Check}

Where possible a zeroth order sanity check on the observations are performed. For example, the observations of $\mathrm{HCl}$ should not be greater than the total atmospheric loading of chlorine, $\mathrm{ClO}_{\mathrm{y}}$, and the observations of $\mathrm{HNO}_{3}$ should not be greater than the total atmospheric loading of nitrogen, $\mathrm{NO}_{\mathrm{y}}$. For this sanity check an 81 year run of the Goddard Space Flight Center (GSFC) two-dimensional chemistry and transport model run from 1970 to 2050 is used (Fleming et al., 1999). This model run was used for international assessments of ozone depletion and is constrained by the recommended emission inventories of the various source gases. During the period 1992 to 2000 it is constrained with the observed residual circulation and gives realistic $\mathrm{NO}_{\mathrm{y}}, \mathrm{ClO}_{\mathrm{y}}$, and $\mathrm{BrO}_{\mathrm{y}}$ distributions.

\section{3 $\mathrm{ClO}_{\mathrm{y}}, \mathrm{BrO}_{\mathrm{y}}$, and $\mathrm{NO}_{\mathrm{y}}$}

The fields of total $\mathrm{ClO}_{\mathrm{y}}, \mathrm{BrO}_{\mathrm{y}}$, and $\mathrm{NO}_{\mathrm{y}}$ in our assimilation were taken from the GSFC 2D model run just mentioned (Fleming et al., 1999). The 2D model transport captures much of the qualitative structure and seasonal variability observed in stratospheric long lived tracers, such as isolation of the tropics and the southern hemisphere winter polar vortex, the well-mixed surf-zone region of the winter subtropics and midlatitudes, and the latitudinal and seasonal variations of total ozone. The generally good model-measurement agreement of the 2-D tracer simulations demonstrate that a successful formulation of zonal mean transport processes can be constructed from currently available atmospheric data sets (Fleming et al., 1999).

\subsection{Accessing Model Uncertainty}

A major new feature of this study is the detail and care with which the observation and modeling uncertainties were determined. At each time step the model uncertainty is accessed in detail by performing a set of sensitivity experiments. The model is cast in equivalent PV latitude, potential temperature $\left(\phi_{e}-\theta\right)$ coordinates that are derived from daily meteorological analyses (UKMO, ECMWF or GEOS). For each analysis grid cell in the flow tracking coordinates we have a probability distribution function (PDF) of temperatures, pressures, geographic latitudes (determining the solar illumination) and sulfate aerosol loadings (derived from daily SAGE and HALOE observations). The temperature, pressure, geographic latitude and sulfate aerosol loading used for the chemical analysis of each grid cell in the flow tracking coordinates is the median value of the PDF. In order to continuously access the representativeness uncertainty for each grid cell associated with the full PDF of temperatures, pressures, geographic latitudes and sulfate aerosol loadings in each grid cell an ensemble of sensitivity experiments is performed at each time step. The average deviation from the median is used as a robust estimator of the width of the PDF and the time step is repeated for the median \pm average deviation of the temperature, pressure, geographic latitude and sulfate aerosol loading. This gives a total of eight simulations for each time step that allow a continuous real assessment of 
the model representativeness uncertainty associated with the analyses coordinate grid.

\section{Chemical Kalman Filter}

Khattatov et al. (1999) applied the Kalman filter for synoptic mapping of short-lived species using UARS data. However they ignored possible observational biases and skill scores. Nor did they address the issue of mass non-conservation that can occur. We have demonstrated how use of sophisticated mathematical techniques in atmospheric chemistry can help with data quality control and understanding limitations of modern instruments and models. This aspect is expected to be particularly important in the near future as more and more satellite-based instruments are being deployed and scientific community faces a complicated task of integrating and validating the emerging extensive data sets.

The chemical Kalman filter (Khattatov et al., 1999) allows the optimal combination of model simulations and measurements taking into account their respective uncertainties. Consider a model of a physical system represented by operator (generally nonlinear) $\mathcal{M}$, and let vector $\mathbf{x}$ with dimension $\mathrm{N}_{\mathrm{X}}$ be a set of input parameters for the model. So in this case the model of our non-linear chemical system is represented by $\mathcal{M}$. These input parameters are used to predict the state of the system, vector $\mathbf{y}$ with dimension $\mathrm{N}_{\mathrm{y}}$ :

$\mathbf{y}=\mathcal{M}(\mathbf{x})$

Assume that vector $\mathbf{x}$ represents the state of a time-dependent numerical photochemical model, i.e. concentrations of modeled species at model grid points in the atmosphere. In the case of a box model that includes $\mathrm{N}$ species, the dimension of vector $\mathbf{x}$ would be $\mathrm{N}$. We will now limit the discussion to the case when $\mathcal{M}$ is used to predict the state of the system at some future time from past state estimates. Formally, in this case

$$
\begin{aligned}
\mathbf{x}=\mathbf{x}_{\mathbf{t}}, & \mathbf{y}=\mathbf{x}_{\mathbf{t}+\Delta \mathbf{t}} \\
\text { and } \mathbf{x}_{\mathbf{t}+\Delta \mathbf{t}} & =\mathcal{M}\left(t, \mathbf{x}_{\mathbf{t}}\right)
\end{aligned}
$$

Let vector $\mathbf{y}_{o}$ contain observations of the state (hence subscript o). Usually, the dimension of $\mathbf{y}_{o}$ is less than $\mathrm{N}_{\mathrm{y}}$, the dimension of the model space, since not all model species are usually observed. The connection between $\mathbf{y}_{o}$ and $\mathbf{y}$ can be established through the so-called observational operator $\mathcal{H}$ :

$\mathbf{y}_{\mathbf{o}}=\mathcal{H}(\mathbf{y})$

Combining equations (1) and (4), we get

$\mathbf{y}_{\mathbf{o}}=\mathcal{H}(\mathcal{M}(\mathbf{x}))$

We now assume that that the probability density functions associated with $\mathbf{x}$ and $\mathbf{y}$ can be satisfactorily approximated by Gaussian functions:

$P D F(\mathbf{y}) \sim \exp \left(-\frac{\left(\mathbf{y}-\mathbf{y}_{\mathbf{t}}\right)^{T} \mathcal{C}^{-1}\left(\mathbf{y}-\mathbf{y}_{\mathbf{t}}\right)}{2}\right)$

where $\mathbf{y}_{t}$ is the true value of $\mathbf{y}$ and $\mathcal{C}$ is the corresponding error covariance matrix. Its diagonal elements are the uncertainties (standard deviations) of $\mathbf{y}$, and the off-diagonal elements represent correlation between uncertainties of different elements of vector $\mathbf{y}$. The covariance matrix $\mathcal{C}$ is defined as

$\mathcal{C}=\left\langle\left(\mathbf{y}-\mathbf{y}_{\mathbf{t}}\right)\left(\mathbf{y}-\mathbf{y}_{\mathbf{t}}\right)^{T}\right\rangle$

where angle brackets represent averaging over all available realizations of $\mathrm{y}$.

For most practical applications we need to introduce the linear approximation. In the linear approximation we assume that for small perturbations of the parameter vector $\Delta \mathbf{x}$ the following is approximately true:

$\mathcal{M}(\mathbf{x}+\Delta \mathbf{x})=\mathcal{M}(\mathbf{x})+\mathcal{L} \Delta \mathbf{x}$

Formally, $\mathcal{L}$ is a derivative of $\mathcal{M}$ with respect to $\mathrm{x}$ :

$\mathcal{L}=\frac{d \mathcal{M}}{d \mathbf{x}}$

For small variations of $\mathbf{x}$ one can show that the evolution of error covariance matrix $\mathcal{C}_{t}$ is given by:

$\mathcal{C}_{t+\Delta t}=\mathcal{L C}_{t} \mathcal{L}^{T}+\mathcal{Q}$

Matrix $\mathcal{Q}$ is the error covariance matrix introduced to take into account uncertainties of the model calculations. The Kalman filter equations are

$$
\begin{aligned}
& \mathbf{x}_{\mathbf{t}+\Delta \mathbf{t}}=\mathcal{M}\left(t, \mathbf{x}_{\mathbf{t}}\right) \\
& \mathcal{C}_{t+\Delta t}=\mathcal{L} \mathcal{C}_{t} \mathcal{L}^{T}+\mathcal{Q} \\
& \hat{\mathbf{x}}_{\mathbf{t}}=\mathbf{x}_{\mathbf{t}}+\mathcal{C}_{t} \mathcal{H}^{T}\left(\mathcal{H C} \mathcal{C}_{t} \mathcal{H}^{T}+\mathcal{O}\right)^{-1}\left(\mathbf{y}_{\mathbf{o}}-\mathcal{H} \mathbf{x}_{\mathbf{t}}\right) \\
& \quad \hat{\mathcal{C}}_{t}=\mathcal{C}_{t}+\mathcal{C}_{t} \mathcal{H}^{T}\left(\mathcal{H} \mathcal{C}_{t} \mathcal{H}^{T}+\mathcal{O}\right)^{-1} \mathcal{H C} \mathcal{C}_{t}
\end{aligned}
$$

$\mathcal{O}$ is the observation error covariance matrix. At the end of each analysis period the model value $\left(\mathbf{x}_{t}\right)$ and the corresponding observation $\left(\mathbf{y}_{o}\right)$ are 'mixed' (see Eq. 11) with weights inversely proportional to their respective errors to produce the analysis, $\hat{\mathbf{x}}_{\mathbf{t}}$. Then the model is integrated forward in time starting from the obtained analysis. Once an observation has been incorporated in the model, the analysis error covariance should be updated to reflect this (see Eq. 12). In the absence of observations, the model state is updated using Eq. (3), while evolution of the error covariance is obtained from the linearized model equations as in Eq. (10).

If no observations are available, then

$\hat{\mathbf{x}}_{\mathbf{t}}=\mathbf{x}_{\mathbf{t}}$
$\hat{\mathcal{C}}_{\mathbf{t}}=\mathcal{C}_{\mathbf{t}}$

The following sections examine some of the roles halogens play in tropospheric chemistry. 
Contributions to $\mathrm{CH}_{3}$ production on October 15, 1991 at local solar noon.

(a)

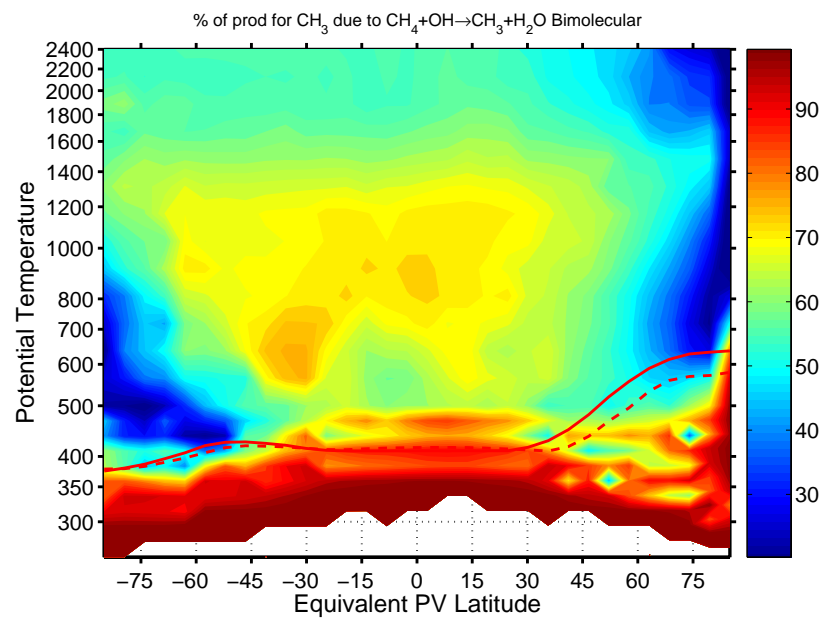

\% of prod for $\mathrm{CH}_{3}$ due to $\mathrm{Cl}_{+} \mathrm{CH}_{4} \rightarrow \mathrm{HCl}+\mathrm{CH}_{3}$ Bimolecular

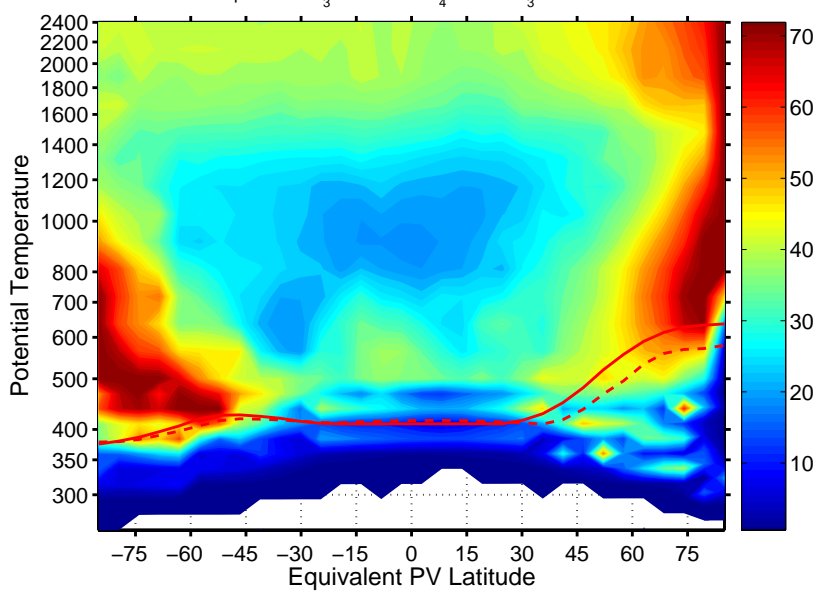

Contributions to $\mathrm{CH}_{3}$ production on January 15,1993 at local solar noon.
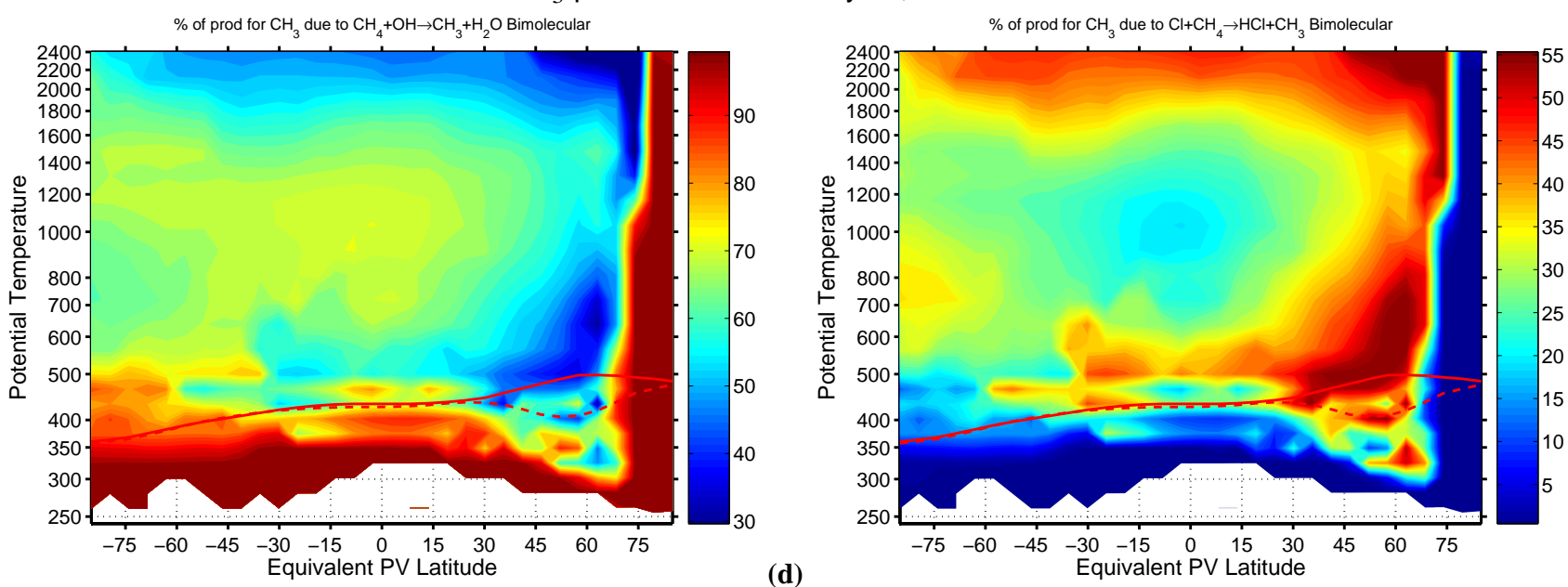

Fig. 2. Based on the analyses produced by chemical data assimilation system panel (a) shows the percentage of the initiation of methane oxidation due to $\mathrm{OH}$ for 15 October 1991. At first glance it confirms the conventional position that in the free-troposphere the initiation by $\mathrm{OH}$ is all that needs to be considered. However, on closer examination it can be seen that there are extensive regions within the troposphere where the initiation of methane oxidation due to $\mathrm{Cl}(\mathrm{Panel}(\mathbf{b}))$ contributes more than $10 \%$ and some regions where it contributes up to $50 \%$. The regions of significant initiation by $\mathrm{Cl}$ are, as would be expected, in the region below the polar vortex, and more surprisingly in northern mid latitudes. The northern mid-latitude feature persists. For example, it can be seen that the mid-latitude role of chlorine initiation is greater in January 1993 (panel (d)). Panels (c) and (d) are the analogues to panels (a) and (b) for 15 January 1993. It can be seen that the northern mid-latitude role of chlorine initiation is slightly greater than for 1991.

\section{Initiation of Hydrocarbon Oxidation}

Methane and hydrocarbon oxidation are some of the most significant atmospheric chemical processes. The hydroxyl radical $(\mathrm{OH})$ is an important cleansing agent of the lower atmosphere, in particular, it provides the dominant sink for $\mathrm{CH}_{4}$ and HFCs as well as the pollutants $\mathrm{NO}_{\mathrm{x}}, \mathrm{CO}$ and VOCs. Once formed, tropospheric $\mathrm{OH}$ reacts with $\mathrm{CH}_{4}$ or $\mathrm{CO}$ within seconds. It is generally accepted that the local abundance of $\mathrm{OH}$ is controlled by the local abundances of $\mathrm{NO}_{\mathrm{x}}, \mathrm{CO}$, VOCs, $\mathrm{CH}_{4}, \mathrm{O}_{3}$, and $\mathrm{H}_{2} \mathrm{O}$ as well as the intensity of solar
$\mathrm{UV}$; and thus it varies greatly with time of day, season, and geographic location (Houghton and Ding, 2001).

Methane oxidation is usually initiated by hydrogen abstraction reactions such as

$$
\begin{aligned}
\mathrm{OH}+\mathrm{CH}_{4} & \longrightarrow \mathrm{CH}_{3}+\mathrm{H}_{2} \mathrm{O} \\
\mathrm{O}\left({ }^{1} \mathrm{D}\right)+\mathrm{CH}_{4} & \longrightarrow \mathrm{CH}_{3}+\mathrm{OH} \\
\mathrm{Cl}+\mathrm{CH}_{4} & \longrightarrow \mathrm{CH}_{3}+\mathrm{HCl} \\
\mathrm{Br}+\mathrm{CH}_{4} & \longrightarrow \mathrm{CH}_{3}+\mathrm{HBr}
\end{aligned}
$$

The rate at which hydrogen is abstracted from $\mathrm{CH}_{4}$ by $\mathrm{OH}$ and $\mathrm{Cl}$ is a strong function of temperature, 
October 15, 1991 at local solar noon.

(a)

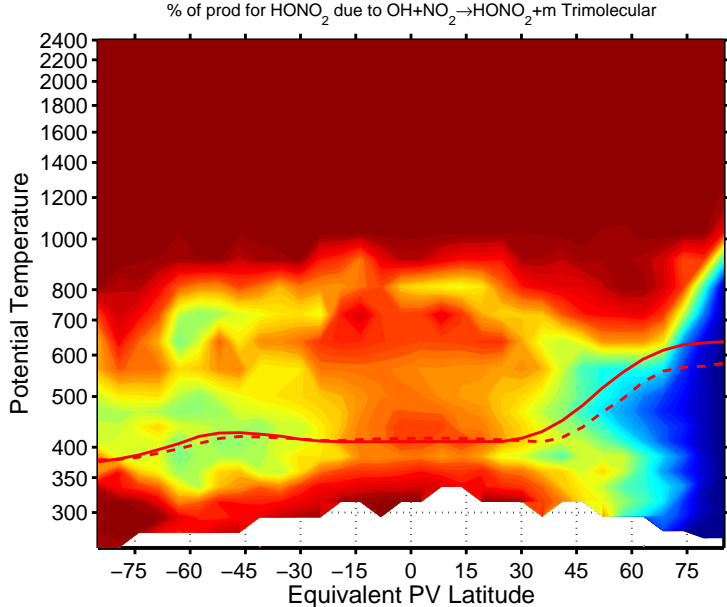

$\%$ of prod for $\mathrm{HONO}_{2}$ due to $\mathrm{H}_{2} \mathrm{O}+\mathrm{ClONO}_{2} \rightarrow \mathrm{HOCl}+\mathrm{HONO}_{2}$ (Heterogeneous SA)
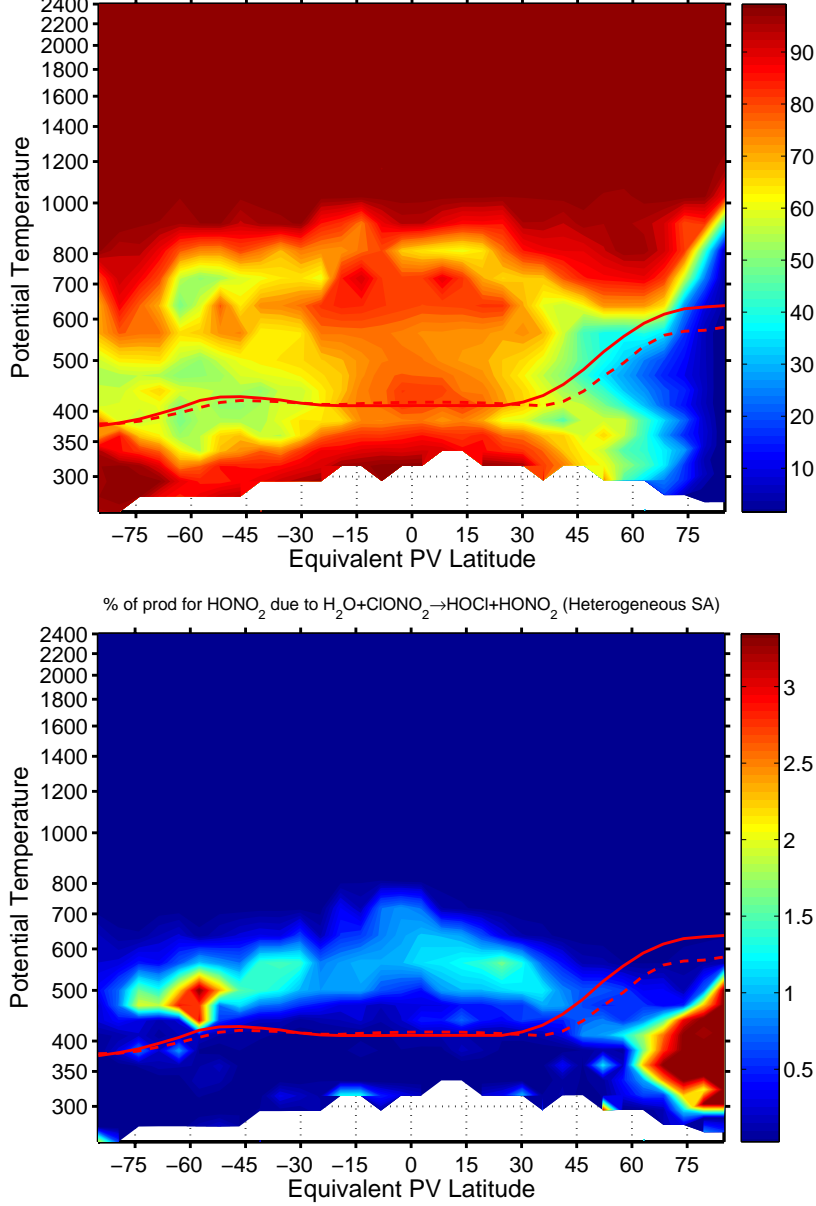

$\%$ of prod for $\mathrm{HONO}_{2}$ due to $\mathrm{H}_{2} \mathrm{O}_{\mathrm{N}} \mathrm{N}_{2} \rightarrow \mathrm{HONO}_{2}+\mathrm{HONO}_{2}$ (Heterogeneous $\mathrm{SA}$ )

(b)

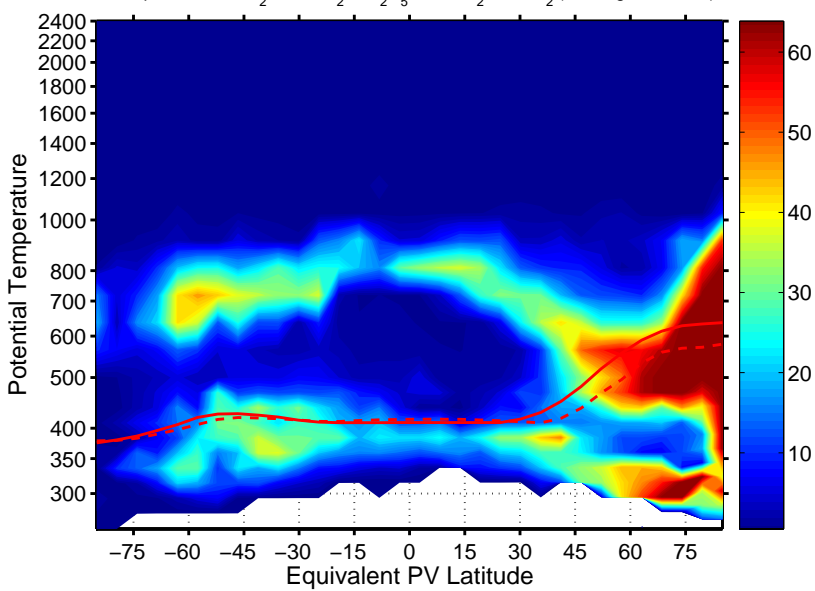

$\%$ of prod for $\mathrm{HONO}_{2}$ due to $\mathrm{H}_{2} \mathrm{O}+\mathrm{BrONO}_{2} \rightarrow \mathrm{HOBr}+\mathrm{HONO}_{2}$ (Heterogeneous $\mathrm{SA}$ )

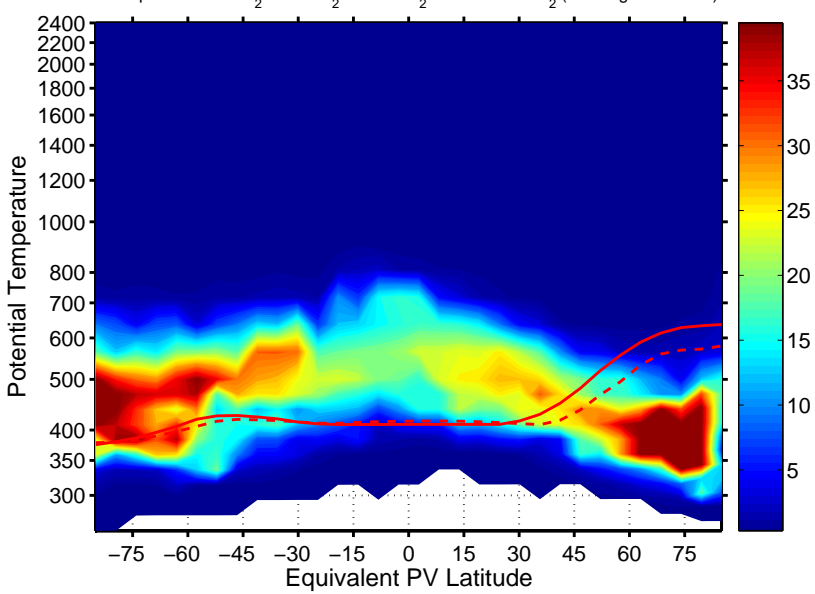

Fig. 3. The contribution of four of the main $\mathrm{HNO}_{3}$ production channels. It is well known that two of the key nitric acid production channels in the troposphere are the bimolecular reaction of $\mathrm{OH}$ with $\mathrm{NO}_{2}$ (panel (a)) and the heterogeneous hydrolysis of $\mathrm{N}_{2} \mathrm{O}_{5}$ on sulphate aerosols (panel (b)). In the stratosphere the heterogeneous hydrolysis of $\mathrm{ClONO}_{2}$ (panel (c)) and $\mathrm{BrONO}_{2}($ panel (d)) is also routinely considered. It can be seen that they are also significant sources of $\mathrm{HNO}_{3}$ in the free troposphere.

altitude, and the total reactive chlorine loading $\left(\mathrm{ClO}_{\mathrm{y}}=2 \mathrm{Cl}_{2}+\mathrm{Cl}+\mathrm{ClO}+2 \mathrm{Cl}_{2} \mathrm{O}_{2}+\mathrm{HCl}+\mathrm{HOCl}+\mathrm{ClONO}_{2}\right)$. It should be noted that Reaction (4) is very slow and just included for the sake of completeness.

Initiation of methane oxidation by $\mathrm{Cl}$ is a strong function of $\mathrm{ClO}_{\mathrm{y}}$. Burnett and Burnett (1995) have inferred from their $\mathrm{OH}$ column measurements that chlorine is likely to be involved in the initiation and oxidation of methane. In agreement with this, Fig. 2 shows that significant initiation of methane oxidation is due to $\mathrm{Cl}$.

However, the halogen initiation and catalysis of hydrocarbons is not usually considered in global chemistry models. This is not due to a lack of kinetic knowledge but rather an assumption that halogens play a minor role outside of the boundary layer and stratosphere (Johnston and Podolske, 1978; Cicerone et al., 1983; Farman et al., 1985). Figure 2 shows that in the lower stratosphere and even in the free tro- posphere, halogen-catalyzed, and halogen-initiated, methane oxidation can be important. Halogen-catalyzed methane oxidation can play a significant role in the production of $\mathrm{HO}_{\mathrm{x}}$ $\left(=\mathrm{H}+\mathrm{OH}+\mathrm{HO}_{2}\right)$ radicals (Lary and Toumi, 1997) in just the region where it is usually accepted that nitrogen-catalyzed methane oxidation is one of the main sources of ozone (Houghton and Ding, 2001). Aspects of methane oxidation by halogens has been previously mentioned by Crutzen et al. (1992); Burnett and Burnett (1995) and the mechanism specifically described by Lary and Toumi (1997).

Figure 1 panels (a) to (d) show the global ozone, nitric acid, methane and hydrochloric acid analyses from the surface up to the lower mesosphere produced by chemical data assimilation for mid-October 1991. Based on the analyses produced by chemical data assimilation system Fig. 1 panel (e) shows the percentage of the initiation of methane oxidation due to $\mathrm{OH}$. At first glance it confirms the conventional 
October 15, 1991 at local solar noon.

(a)

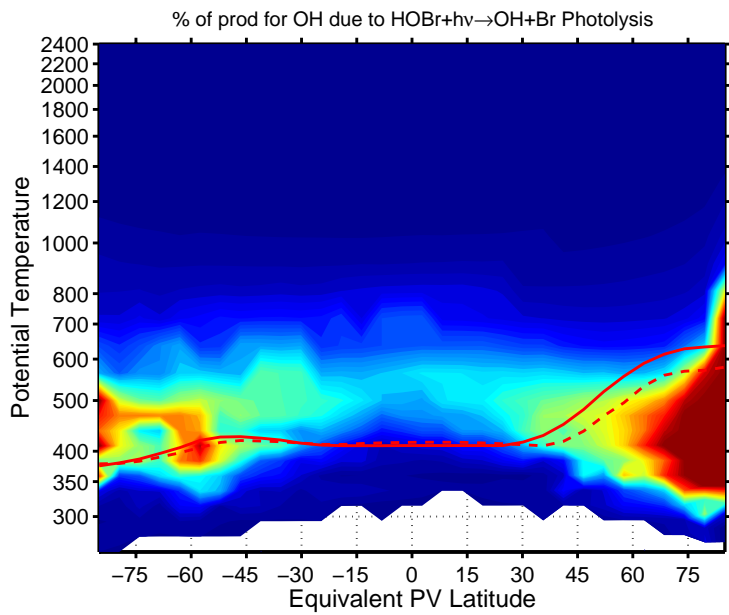

$\%$ of loss for $\mathrm{NO}$ due to $\mathrm{ClO}+\mathrm{NO} \rightarrow \mathrm{Cl}+\mathrm{NO}_{2}$ Bimolecular

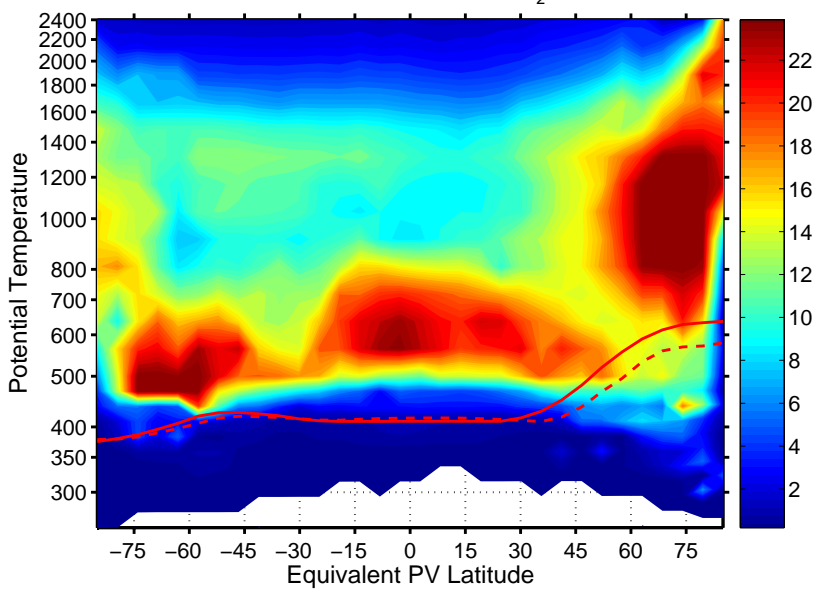

$\%$ of loss for $\mathrm{HO}_{2}$ due to $\mathrm{BrO}+\mathrm{HO}_{2} \rightarrow \mathrm{HOBr}+\mathrm{O}_{2}$ Bimolecular

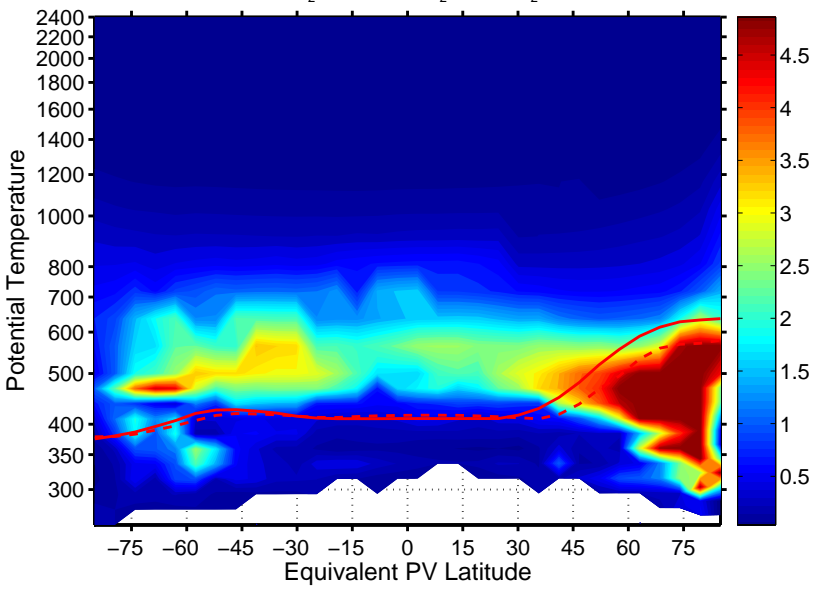

$\%$ of loss for $\mathrm{NO}$ due to $\mathrm{BrO}+\mathrm{NO} \rightarrow \mathrm{Br}+\mathrm{NO}_{2}$ Bimolecular

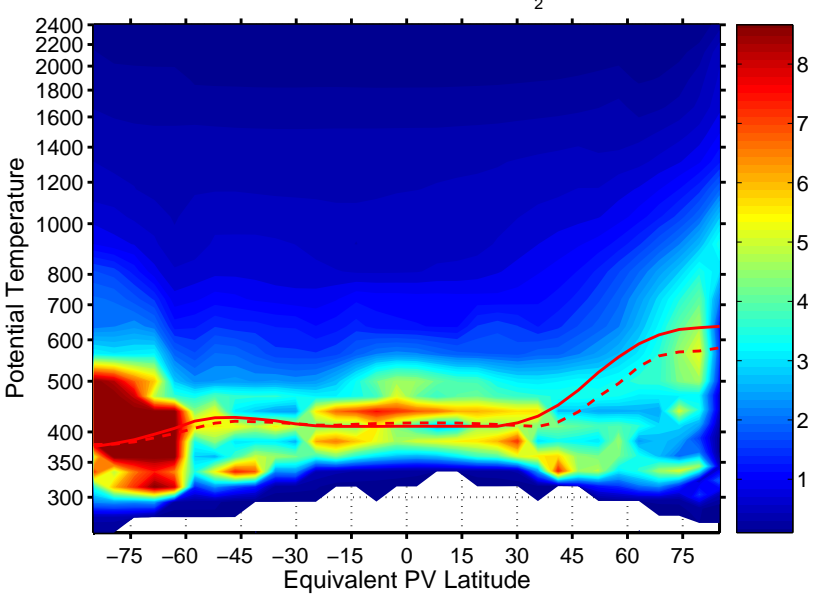

Fig. 4. $\mathrm{HOBr}$ is readily photolyzed in the visible and yields $\mathrm{OH}$. Panel (a) shows that $\mathrm{HOBr}$ photolysis can contribute close to $10 \%$ of the total $\mathrm{OH}$ production rate at high latitudes in the free-troposphere. Likewise panel (b) shows that the production of HOBr by the bimolecular reaction of $\mathrm{BrO}$ with $\mathrm{HO}_{2}$ contributes more than $5 \%$ to the total $\mathrm{HO}_{2}$ loss rate at high latitudes in the free-troposphere. The tropospheric partitioning of $\mathrm{NO}$ and $\mathrm{NO}_{2}$ is affected by halogen interactions. Panel (c) shows that there are large regions in northern mid-latitudes and below the polar vortex where more than $10 \%$ of the loss of $\mathrm{NO}$ is due to reaction with $\mathrm{ClO}$. Panel (d) shows that for much of the free-troposphere the reaction of $\mathrm{NO}$ with $\mathrm{BrO}$ contributes more than $5 \%$ to the loss of NO.

position that in the free-troposphere the initiation by $\mathrm{OH}$ is all that needs to be considered. However, on closer examination it can be seen that there are extensive regions within the troposphere where the initiation of methane oxidation due to $\mathrm{Cl}$ (Fig. 1 panel (f)) contributes more than $10 \%$ and some regions where it contributes up to $50 \%$. The regions of significant initiation by $\mathrm{Cl}$ are, as would be expected, in the region below the polar vortex, and more surprisingly in northern mid latitudes. The northern mid-latitude feature persists. For example, it can be seen that the mid-latitude role of chlorine initiation is greater in January 1993 (Fig. 2 panel (d)).

\section{Production of Nitric Acid}

It is well known (Brasseur and Solomon, 1987; Wayne, 1991; DeMore et al., 2000) that two of the key nitric acid production channels are the bimolecular reaction of $\mathrm{OH}$ with $\mathrm{NO}_{2}$ and the heterogeneous hydrolysis of $\mathrm{N}_{2} \mathrm{O}_{5}$ on sulphate aerosols (please see Fig. 3a and b). In the stratosphere the heterogeneous hydrolysis of $\mathrm{ClONO}_{2}$ and $\mathrm{BrONO}_{2}$ are also routinely considered (DeMore et al., 2000). However, as halogens are often normally not considered in models of the free troposphere these channels are not normally considered in the troposphere. Figure $3 \mathrm{c}$ shows that the hydrolysis of $\mathrm{BrONO}_{2}$ alone can contribute more than $35 \%$ to the $\mathrm{HNO}_{3}$ production rate (this percentage depends on the reaction probability, here 0.9 was used). Therefore excluding 
halogen chemistry from global chemical models can lead to a significant error in these regions, yet another reason for considering halogen chemistry in the free troposphere.

\section{Partitioning of $\mathrm{OH}$ and $\mathrm{HO}_{2}$}

$\mathrm{HOBr}$ is readily photolyzed in the visible and yields $\mathrm{OH}$ (Rattigan et al., 1996). Figure 4a shows that $\mathrm{HOBr}$ photolysis can contribute close to $10 \%$ of the total $\mathrm{OH}$ production rate at high latitudes in the free-troposphere. Likewise Figure $4 \mathrm{~b}$ shows that the production of $\mathrm{HOBr}$ by the bimolecular reaction of $\mathrm{BrO}$ with $\mathrm{HO}_{2}$ contributes more than $5 \%$ to the total $\mathrm{HO}_{2}$ loss rate at high latitudes in the free-troposphere.

\section{Partitioning of $\mathrm{NO}$ and $\mathrm{NO}_{2}$}

The tropospheric partitioning of $\mathrm{NO}$ and $\mathrm{NO}_{2}$ is affected by halogen interactions. Figure 4 panel (c) shows that there are large regions in northern mid-latitudes and below the southern polar vortex where more than $10 \%$ of the loss of NO is due to reaction with $\mathrm{ClO}$. Figure 4 panel (d) shows that for much of the free-troposphere the reaction of $\mathrm{NO}$ with $\mathrm{BrO}$ contributes more than $5 \%$ to the loss of NO.

\section{Conclusions}

A careful constraint of a photochemical modelling system using chemical data assimilation and a variety of atmospheric observations has been conducted. A detailed analysis of the results shows that halogens are playing a role in the chemistry of the free troposphere. In particular, methane oxidation is initiated by $\mathrm{Cl}$ as well as $\mathrm{OH}$ in the troposphere. The $\mathrm{Cl}$ initiation of methane oxidation can contribute more than $10 \%$ to the total rate of initiation below the polar vortex and in mid-latitudes. In addition, the hydrolysis of $\mathrm{BrONO}_{2}$ alone can contribute more than $35 \%$ of the $\mathrm{HNO}_{3}$ production rate in the free troposphere. The partitioning of $\mathrm{NO}$ and $\mathrm{NO}_{2}$ in the free troposphere is also significantly affected by halogen reactions.

Acknowledgements. It is a pleasure to acknowledge: NASA for a distinguished Goddard Fellowship in Earth Science and for research support; The Royal Society for a Royal Society University Research Fellowship; The government of Israel for an Alon Fellowship; The NERC, EU, and ESA for research support.

Edited by: R. Sander

\section{References}

Ackerman, M., Brogniez, C., Diallo, B., et al.: European validation of SAGE II aerosol profiles, J. Geophys. Res., 94, 8399-8411, 1989.

Anderson, D.: The troposphere-stratosphere radiation-field at twilight - A spherical model, Planet. Space Sci., 31, 1517-1523, 1983.

Atkinson, R.: An observational study of the Austral spring stratosphere: Dynamics, Ozone transport and the 'Ozone dilution effect, Ph.D. Thesis, Massachusetts Institute of Technology, 1993.

Bauman, J. J., Russell, P. B., Geller, M. A., and Hamill, P.: A stratospheric aerosol climatology from SAGE II and CLAES measurements: 1. methodology, J. Geophys. Res. (Atmos.), 108, AAC 6-1 AAC 6-3, 2003.

Becker, G., Grooss, J., McKenna, D., and Muller, R.: Stratospheric photolysis frequencies: Impact of an improved numerical solution of the radiative transfer equation, J. Atmos. Chem., 37, $217-$ 229, 2000.

Brasseur, G. and Solomon, S.: Aeronomy of the Middle Atmosphere : Chemistry and Physics of the Stratosphere and Mesosphere, Atmospheric Science Library, D Reidel Pub Co, second edn., 1987.

Burnett, E. and Burnett, C.: Enhanced production of stratospheric $\mathrm{OH}$ from methane oxidation at elevated reactive chlorine levels in Northern midlatitudes, J. Atmos. Chem., 21, 13-41, 1995.

Cicerone, R. J., Walters, S., and Liu, S. C.: Non-linear response of stratospheric ozone column to chlorine injections, J. Geophys. Res. (Atmos.), 88, 3647-3661, 1983.

Crutzen, P. J., Müller, R. Brühl, C., and Peter, T.: On the potential importance of the gas-phase reaction $\mathrm{CH}_{3} \mathrm{OO}+\mathrm{ClO} \longrightarrow \mathrm{ClOO}$ $+\mathrm{CH}_{3} \mathrm{O}$ and the heterogeneous reaction $\mathrm{HOCl}+\mathrm{HCl} \longrightarrow \mathrm{H}_{2} \mathrm{O}$ $+\mathrm{Cl}_{2}$ in ozone hole chemistry, Geophys. Res. Lett., 19, 11131116, 1992.

Danielsen, E.: Stratospheric-tropospheric exchange based on radioactivity ozone and potential vorticity, J. Atmos. Sci., 25, 502-, 1968.

DeMore, W. B., Howard, C. J., Sander, S. P., Ravishankara, A. R., Golden, D. M., Kolb, C. E., Hampson, R. F. Molina, M. J., and Kurylo, M. J.: Chemical kinetics and photochemical data for use in stratospheric modeling, supplement to evaluation 12: Update of key reactions, JPL Publ. 00-3, NASA JPL, 2000.

Dickerson, R. R., Rhoads, K. P., Carsey, T. P., Oltmans, S. J., Burrows, J. P., and Crutzen, P. J.: Ozone in the remote marine boundary layer: A possible role for halogens, J. Geophys. Res. (Atmos.), 104, 21 385-21 395, 1999.

Douglass, A., Rood, R., Stolarski, R., Schoeberl, M., Proffitt, M., Margitan, J., Loewenstein, M., Podolske, J., and Strahan, S.: Global 3-dimensional constituent fields derived from profile data, Geophys. Res. Lett., 17, 525-528, 1990.

Farman, J. C., Gardiner, B. G., and Shanklin, J. D.: Large losses of total ozone in antarctica reveal seasonal $\mathrm{ClO}_{\mathrm{X}} / \mathrm{NO}_{\mathrm{X}}$ interaction, Nature, 315, 207-210, 1985.

Fisher, M. and Lary, D.: Lagrangian 4-dimensional variational data assimilation of chemical-species, Q. J. R. Meteorol. Soc., 121, 1681-1704, 1995.

Fleming, E. L., Jackman, C. H., Stolarski, R. S., and Considine, D. B.: Simulation of stratospheric tracers using an improved empirically based two-dimensional model transport formulation, J. Geophys. Res. (Atmos.), 104, 23 911-23 934, 1999. 
Froidevaux, L., Read, W. G., Lungu, T. A., Cofield, R. E., Fishbein, E. F., Flower, D. A., Jarnot, R. F., Ridenoure, B. P., Shippony, Z., Waters, J. W., Margitan, J. J., McDermid, I. S., Stachnik, R. A., Peckham, G. E., Braathen, G., Deshler, T., Fishman, J., Hofmann, D. J., and Oltmans, S. J.: Validation of UARS microwave limb sounder ozone measurement, J. Geophys. Res. (Atmos.), 101, 10 017-10 060, 1996.

Haynes, P. H. and McIntyre, M. E.: On the conservation and impermeability theorems for potential vorticity, J. Atmos. Sci., 47, 2021-2031, 1990.

Hendricks, J., Lippert, E., Petry, H., and Ebel, A.: Heterogeneous reactions on and in sulfate aerosols: Implications for the chemistry of the midlatitude tropopause region, J. Geophys. Res. (Atmos.), 104, 5531-5550, 1999.

Hervig, M., Russell, J., Gordley, L., Drayson, S., Stone, K., Thompson, R., Gelman, M., McDermid, I., Hauchecorne, A., Keckhut, P., McGee, T., Singh, U., and Gross, M.: Validation of temperature measurements from the halogen occultation experiment, $\mathrm{J}$. Geophys. Res., 101, 10277-10 285, 1996.

Hervig, M. E. and Deshler, T.: Stratospheric aerosol surface area and volume inferred from HALOE, CLAES, and ILAS measurements, J. Geophys. Res. (Atmos.), 103, 25 345-25 352, 1998.

Hervig, M. E., Russell, J. M., Gordley, L. L., Park, J. H., and Drayson, S. R.: Observations of aerosol by the HALOE experiment onboard UARS - a preliminary validation, Geophys. Res. Lett., 20, 1291-1294, 1993.

Hoskins, B.: Towards a PV-Theta view of the general-circulation, Tellus, Ser. A., 43, 27-35, 1991.

Hoskins, B., McIntyre, M., and Robertson, A.: On the use and significance of isentropic potential vorticity maps, Q. J. R. Meteorol. Soc., 111, 877-946, 1985.

Houghton, J. and Ding, Y. (Eds): Climate Change 2001: The Scientific Basis, IPCC, UNEP, 2001.

Johnston, H. S. and Podolske, J.: Interpretation of stratospheric photochemistry, Rev. Geophys., 16, 491, 1978.

Khattatov, B., Gille, J., Lyjak, L., Brasseur, G., Dvortsov, V., Roche, A., and Waters, J.: Assimilation of photochemically active species and a case analysis of UARS data, J. Geophys. Res. (Atmos.), 104, 18 715-18 737, 1999.

Lait, L., Schoeberl, M., Newman, P., Proffitt, M., Loewenstein, M., Podolske, J., Strahan, S., Chan, K., Gary, B., Margitan, J., Browell, E., Mccormick, M., and Torres, A.: Reconstruction of $\mathrm{O}_{3}$ and $\mathrm{N}_{2} \mathrm{O}$ fields from ER-2, DC-8, and balloon observations, Geophys. Res. Lett., 17, 521-524, 1990.

Lary, D.: Gas phase atmospheric bromine photochemistry, J. Geophys. Res., 101, 1505-1516, 1996.

Lary, D.: Representativeness uncertainty in chemical data assimilation highlight mixing barriers, Atmospheric Science Letters, 5, 35-41, 2003.

Lary, D. and Pyle, J.: Diffuse-radiation, twilight, and photochemistry: 1., J. Atmos. Chem., 13, 373-392, 1991a.

Lary, D. and Pyle, J.: Diffuse-radiation, twilight, and photochemistry: 2., J. Atmos. Chem., 13, 393-406, 1991 b.

Lary, D. and Toumi, R.: Halogen-catalyzed methane oxidation, J. Geophys. Res., 102, 23 421-23 428, 1997.

Lary, D., Chipperfield, M., Pyle, J., Norton, W., and Riishojgaard, L.: 3-dimensional tracer initialization and general diagnostics using equivalent PV latitude-potential-temperature coordinates, Q. J. R. Meteorol. Soc., 121, 187-210, 1995a.
Lary, D., Chipperfield, M., and Toumi, R.: The potential impact of the reaction $\mathrm{OH}+\mathrm{ClO} \longrightarrow \mathrm{HCl}+\mathrm{O}_{2}$ on polar ozone photochemistry, J. Atmos. Chem., 21, 61-79, 1995 b.

Lary, D. J., Khattatov, B., and Mussa, H. Y.: Chemical data assimilation: A case study of solar occultation data from the atlas 1 mission of the atmospheric trace molecule spectroscopy experiment (atmos), J. Geophys. Res. (Atmos.), 108, 2003.

Marenco, A., Thouret, V., Nedelec, P., Smit, H., Helten, M., Kley, D., Karcher, F., Simon, P., Law, K., Pyle, J., Poschmann, G., Von Wrede, R., Hume, C., and Cook, T.: Measurement of ozone and water vapor by airbus in-service aircraft: The MOZAIC airborne program, an overview, J. Geophys. Res. (Atmos.), 103, 25 631-25 642, 1998.

Massie, S., Randel, W., Wu, F., Baumgardner, D., and Hervig, M.: Halogen occultation experiment and stratospheric aerosol and gas experiment ii observations of tropopause cirrus and aerosol during the 1990s, J. Geophys. Res. (Atmos.), 108, 2003.

McIntyre, M. and Palmer, T.: Breaking planetary-waves in the stratosphere, Nature, 305, 593-600, 1983.

McIntyre, M. and Palmer, T.: The surf zone in the stratosphere, J. Atmos. Terr. Phys., 46, 825-849, 1984.

Meier, R., Anderson, D., and Nicolet, M.: Radiation-field in the troposphere and stratosphere from 240-1000 nm. 1., Generalanalysis, Planet. Space Sci., 30, 923-933, 1982.

Nicolet, M., Meier, R., and Anderson, D.: Radiation-field in the troposphere and stratosphere .2. Numerical-analysis, Planet. Space Sci., 30, 935-983, 1982.

Norton, W.: Breaking rossby waves in a model stratosphere diagnosed by a vortex-following technique for advecting material contours, J. Atmos. Sci., 51, 654-673, 1994.

Oberbeck, V. R., Livingston, J. M., Russell, P. B., Pueschel, R. F., Rosen, J. N., Osborn, M. T., Kritz, M. A., Snetsinger, K. G., and Ferry, G. V.: SAGE-II aerosol validation - selected altitude measurements, including particle micromeasurements, J. Geophys. Res. (Atmos.), 94, 8367-8380, 1989.

Offermann, D. and Conway, R. R.: Crista/mahrsi - preface, J. Geophys. Res. (Atmos.), 104, 16309-16310, 1999.

Press, W., Teukolsky, S., Vetterling, W., and Flannery, B.: Numerical Recipes in Fortran - The Art of Scientific Computing, Cambridge Univ. Press, New York, 2nd edn., 1992.

Proffitt, M., Steinkamp, M., Powell, J., Mclaughlin, R., Mills, O., Schmeltekopf, A., Thompson, T., Tuck, A., Tyler, T., Winkler, R., and Chan, K.: Insitu ozone measurements within the 1987 antarctic ozone hole from a high-altitude ER-2 aircraft, J. Geophys. Res. (Atmos.), 94, 16 547-16 555, 1989.

Proffitt, M., Aikin, K., Margitan, J., Loewenstein, M., Podolske, J., Weaver, A., Chan, K., Fast, H., and Elkins, J.: Ozone loss inside the northern polar vortex during the 1991-1992 winter, Science, 261, 1150-1154, 1993.

Rattigan, O., Lary, D., Jones, R., and Cox, R.: Uv-visible absorption cross sections of gaseous $\mathrm{Br} 2 \mathrm{O}$ and $\mathrm{HOBr}$, J. Geophys. Res., 101, 23 021-23 033, 1996.

Reber, C. A., Trevathan, C. E., Mcneal, R. J., and Luther, M. R.: The upper-atmosphere research satellite (UARS) mission, J. Geophys. Res. (Atmos.), 98, 10 643-10 647, 1993.

Richter, A., Wittrock, F., Eisinger, M., and Burrows, J. P.: Gome observations of tropospheric bro in northern hemispheric spring and summer 1997, Geophys. Res. Lett., 25, 2683-2686, 1998.

Russell, J. M., Gordley, L. L., Park, J. H., Drayson, S. R., Hesketh, 
W. D., Cicerone, R. J., Tuck, A. F., Frederick, J. E., Harries, J. E., and Crutzen, P. J.: The halogen occultation experiment, J. Geophys. Res. (Atmos.), 98, 10 777-10 797, 1993.

Russell, P. B. and McCormick, M. P.: SAGE-II aerosol data validation and initial data use - an introduction and overview, J. Geophys. Res. (Atmos.), 94, 8335-8338, 1989.

Sander, R. and Crutzen, P. J.: Model study indicating halogen activation and ozone destruction in polluted air masses transported to the sea, J. Geophys. Res. (Atmos.), 101, 9121-9138, 1996.

Sander, R., Keene, W. C., Pszenny, A. A. P., Arimoto, R., Ayers, G. P., Baboukas, E., Cainey, J. M., Crutzen, P. J., Duce, R. A., Hönninger, G., Huebert, B. J., Maenhaut, W., Mihalopoulos, N., Turekian, V. C., and Van Dingenen, R.: Inorganic bromine in the marine boundary layer: a critical review, Atmos. Chem. Phys., 3, 1301-1336, 2003,

\section{SRef-ID: 1680-7324/acp/2003-3-1301.}

Santee, M. L., Manney, G. L., Froidevaux, L., Zurek, R. W., and Waters, J. W.: MLS observations of $\mathrm{ClO}$ and $\mathrm{HNO}_{3}$ in the 1996 97 arctic polar vortex, Geophys. Res. Lett., 24, 2713-2716, 1997.

Santee, M. L., Manney, G. L., Froidevaux, L., Read, W. G., and Water, J. W.: Six years of UARS microwave limb sounder $\mathrm{HNO}_{3}$ observations: Seasonal, interhemispheric, and interannual variations in the lower stratosphere, J. Geophys. Res. (Atmos.), 104, 8225-8246, 1999.

Schoeberl, M. and Lait, L.: Conservative-coordinate transformations for atmospheric measurements, in Use of EOS for Studies of Atmospheric Physics, Vol. 115th course of the international school of physics Enrico Fermi, pp. 419-431, 1992.

Schoeberl, M. R., Lait, L. R., Newman, P. A., Martin, R. L., Proffitt, M. H., Hartmann, D. L., Loewenstein, M., Podolske, J., Strahan, S. E., Anderson, J., Chan, K. R., and Gary, B.: Reconstruction of the constituent distribution and trends in the antarctic polar vortex from er-2 flight observations, J. Geophys. Res. (Atmos.), 94, 16815-16845, 1989.
Thomason, L. W.: A diagnostic stratospheric aerosol size distribution inferred from SAGE-II measurements, J. Geophys. Res. (Atmos.), 96, 22 501-22 508, 1991.

Thomason, L. W.: Observations of a new SAGE-II aerosol extinction mode following the eruption of Mt. pinatubo, Geophys. Res. Lett., 19, 2179-2182, 1992.

Vogt, R., Crutzen, P. J., and Sander, R.: A mechanism for halogen release from sea-salt aerosol in the remote marine boundary layer, Nature, 383, 327-330, 1996.

von Glasow, R. and Crutzen, P. J.: Model study of multiphase DMS oxidation with a focus on halogens, Atmos. Chem. Phys., 4, 589608, 2004,

SRef-ID: 1680-7324/acp/2004-4-589.

von Glasow, R., von Kuhlmann, R., Lawrence, M. G., Platt, U., and Crutzen, P. J.: Impact of reactive bromine chemistry in the troposphere, Atmos. Chem. Phys., 4, 2481-2497, 2004,

SRef-ID: 1680-7324/acp/2004-4-2481.

Waters, J. W.: Atmospheric measurements by the MLS experiments: Results from UARS and plans for the future, in CIRA Part III Reference Atmospheres - Trace Constituent Models Comparison with Latest Data, vol. 21 of Advances in Space Research, pp. 1363-1372, Elsevier, 1998.

Wayne, R. P.: Chemistry of Atmospheres, Oxford University Press, second edn., 1991.

WMO, Scientific assessment of stratospheric ozone: 1985, Tech. Rep. 16, Global Ozone Res. and Monitor. Proj., Geneva, Switzerland, 1986.

Wood, S. W., Bodeker, G. E., Boyd, I. S., Jones, N. B., Connor, B. J., Johnston, P. V., Matthews, W. A., Nichol, S. E., Murcray, F. J., Nakajima, H., and Sasano, Y.: Validation of version 5.20 ILAS $\mathrm{HNO}_{3}, \mathrm{CH}_{4}, \mathrm{~N}_{2} \mathrm{O}, \mathrm{O}_{3}$, and $\mathrm{NO}_{2}$ using ground-based measurements at Arrival Heights and Kiruna, J. Geophys. Res. (Atmos.), 107, 2002. 